\title{
Hg-EDTA による臭素イオンとヨゥ素イオンの紫外吸光光度定量
}

\author{
(昭和 41 年 8 月 1 日 受 理)
}

小松寿美雄・野 村 俊 明*1

\begin{abstract}
臭素イオンまたはヨウ秦イオンは Hg-EDTA と反応して紫外部に吸収をもつ錯体を形成するので，とれら錯体の吸光度を測定 して両イオンの吸光光度定量法を行なった。 $p \mathrm{H} 3.5 \sim 7.7$ にした臬素イオン溶液または $p \mathrm{H} 5$ ～8.3にしたヨウ素イオン溶液に $\mathrm{Hg}$-EDTA 溶液の一定過剩量を加え, 水で全容 $50 \mathrm{ml}$ にし，2，3 分放置後，試薬ブランク液を対照にして波長 $250 \mathrm{~m} \mu$ (臭素)ま たは $260 \mathrm{~m} \mu$ (ヨウ素)で吸光度を測定する。これら錯体における臬素イオンまたはヨウ素イオンと Hg-EDTA との当量関係はモ

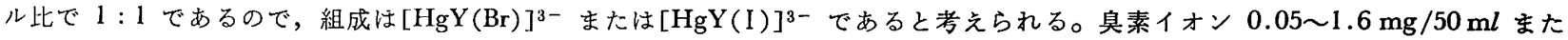
はヨウ素イオン $0.05 \sim 2.0 \mathrm{mg} / 50 \mathrm{ml}$ の浱度範囲で Beer の法則が成立する。モル吸光係数は約 2650 (臭素)および約 4200(ヨウ 素)であって，再現性は非常によい。臭素イオンの定量では $\mathrm{CN}^{-}, \mathrm{SCN}^{-}, \mathrm{I}^{-}, \mathrm{S}^{2-}, \mathrm{Co}^{2+}$ などが， ヨウ素イオンのそれでは $\mathrm{S}^{2-}$ ， $\mathrm{SCN}^{-}, \mathrm{CN}^{-}, \mathrm{Br}^{-}, \mathrm{NH}_{4}{ }^{+}, \mathrm{Co}^{2+}, \mathrm{Ag}^{+}$などの共存が妨害する。
\end{abstract}

\section{1 緒言}

親電子性の陰イオンが $\mathrm{Hg}$-EDTA にさらに配位して，一種の 䤵体をつくる可能性は Schwarzenbach が述べている1)。この事 実のうらづけともいえるがチオシアン酸イオン2)やシアンイオ ン3) は Hg-EDTA とつぎの式のように反応することを著者らは 認めて, 両イオンの吸光光度定量法に応用して良結果を得たので 報告した。ただし， $\mathrm{Hg}$-EDTA を $\mathrm{HgY}^{2-}$ と略記した。

$$
\begin{aligned}
& \mathrm{HgY}^{2-}+\mathrm{SCN}^{-} \longrightarrow[\mathrm{HgY}(\mathrm{SGN})]^{3-} \\
& \mathrm{HgY}^{2-}+\mathrm{CN}^{-} \longrightarrow[\mathrm{HgY}(\mathrm{CN})]^{3-}
\end{aligned}
$$

漞電子性陰イオンの臭素イオンやヨウ素イオンもまた $\mathrm{Hg}$ EDTA と反応して同形式の鉦体 $[\mathrm{HgY}(\mathrm{Br})]^{3-}$ p $[\mathrm{HgY}(\mathrm{I})]^{3-}$ 形成寸ることを認め，吸光光度定量法について検討したので報告 する。なお，代表的な最近の臭素イオンやヨウ素イオンの吸光光 度定量法にはつぎの諸報告がある。たとえば塩化物, 臭化物, ヨ ウ化物の共存における微量の臭素イオン4)ないしヨウ素イオン5) の定量にはテオシアン酸水銀のアルコール溶液と鉄ミョウバンを 用いる方法，接触反応による極微量の臭素イオン67)やヨウ素イ オン8)の定量法, 硝酸水銀(II)-ジフェニルカルバゾンーベンゼン 抽出法による臭素イオンとヨウ素イオンの定量法9)などがある。 本定量法は以上の微量定量法にくらべると感度は劣るが特別の試 薬を必要としないし，操作は簡単，鍇体形成反応もすみやかで榆 量線の再現性も非船に良好であるので, 定量法として利用できる ものと思われる。

\section{2 試薬および装置}

2.1 試 薬

Hg-EDTA 溶液：ドータイト Hg-EDTA を水に溶かし，臭素

*1 Sumio Komatsu, Toshiaki Nomura 信州大学理学部 化学教室, 松本市罚

1) G. Schwarzenbach 著, 吉野諭吉, 他訳, “コンプレク ソン滴定”，共立出版(1958) p. 121 .

2) 小松寿亲雄，野村俊明，日化，87，841(1966).

3）小松寿美雄，野村俊朋，日化，87，845(1966).

4) 岩崎岩次, 内海 喻, 他, 日化, 80, 744(1959).

5) 岩崎岩次, 内海唋, 他, 日化, 80, 749(1959).

6) 塭田 勝, 内海 險, 他, 日化, 80, 753(1959).

7) N. Yonehara, S. Utsumi, I. Iwasaki, Bull. Chem. Soc. Japan, 38, 1887(1965).

8)内海喻, 塩田膝, 他, 日化, 85, 32(1964).

9）友成明久，日化，83，459(1962).
イオンのときは $5 \times 10^{-3} \mathrm{~mol} / l$ 溶液，ヨウ素イオンのときは $1 \times$ $10^{-3} \mathrm{~mol} / l$ 溶液をそれぞれ調製した。

臭素イオン標準液: 和光純薬製特級臭化カリウム $1.192 \mathrm{~g}$ を水 に溶かして $1 l$ にし， $0.1 \mathrm{~N}$ 硝酸銀標準液と $0.05 \mathrm{~N}$ チオシアン 酸アンモニウム標準液とを用いて Volhard 法10)で標定し，これ をうすめて $1 \times 10^{-3} \mathrm{~mol} / l$ 臭素イオン標準液 $(F=0.984,1 \mathrm{~m} l=$ $0.0786 \mathrm{mg} \mathrm{Br}$ )にして使用した。

ヨウ素イオン標準液: 和光製特級ヨウ化カリウム $1.66 \mathrm{~g}$ を水 に溶かして $1 l$ にし，臭素イオンと同様に Volhard 法10)で標定 し, 使用前に 10 倍にうすめて $1 \times 10^{-3} \mathrm{~mol} / l$ ヨウ素イオン標準 液 $(F=0.983,1 \mathrm{~m} l=0.1254 \mathrm{mg} \mathrm{I})$ として使用した。

緩衝液： $0.1 \mathrm{~mol} / l$ リン酸二水素カリウム溶液および $0.1 \mathrm{~mol} /$ $l$ リン酸一水素ナトリウム溶液を調製し, それぞれ所定の $\boldsymbol{p H} に$ なるように混合して使用した。なお， $p \mathrm{H} 5$ 以下は $0.1 \mathrm{~mol} / l$ 酢 酸 $-0.1 \mathrm{~mol} / l$ 酶酸ナトリウム系を, $p \mathrm{H} 8.3$ 以上は $0.1 \mathrm{~mol} / l$ 炭 酸ナトリウム $-0.2 \mathrm{~mol} / l$ 炭酸水素ナトリウム系を使用した。

その他の試薬：すべて市販特級品を使用した。

\section{2 装}

分光光度計は日立製 Perkin Elmer 139 型を使用し，セルは石 英製 $10 \mathrm{~mm}$ 角を使用した。また $p \mathrm{H}$ 測定に日立-堀場製 M-4 型

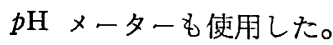

\section{3 定量操作と検量線}

\section{1 定量操作}

臭素イオンまたはヨウ素イオン試料溶液を $50 \mathrm{ml}$ メスフラスコ にとり, $0.1 \mathrm{~mol} / l$ リン酸二水素カリウム $-0.1 \mathrm{~mol} / l$ リン酸一水

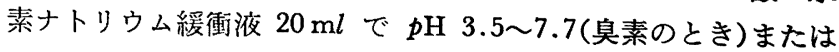
5〜8.3 (ヨウ素のとき)にし, $\mathrm{Hg}$-EDTA 溶液 $10 \mathrm{ml}$ (臭素のとき は $5 \times 10^{-3} \mathrm{~mol} / l$, ヨウ素のときは $2 \times 10^{-3} \mathrm{~mol} / l$ の濃度のもの) を加えて水で標線までうすめる。これを 2,3 分放置後, 石英製 $10 \mathrm{~mm}$ セルに移し, 試薬ブランク液を対照にして波長 $250 \mathrm{~m} \mu$ (臭素)または $260 \mathrm{~m} \mu$ (ヨウ素)で吸光度を測定する。

\section{2 検量線}

$1.6 \mathrm{mg}$ までの臭素イオンまたは $2.0 \mathrm{mg}$ までのヨウ素イオン をとり，定量操作にしたがって濃度と吸光度との関係を示す検量 線を求めたのが図 1である。臭素イオン $0.05 〜 1.6 \mathrm{mg} / 50 \mathrm{ml}$ お

10）たとえば，石橋雅義，“定量分析実験法”，富山房 (1964) p.475. 
よびヨウ素イオン $0.05 \sim 2.0 \mathrm{mg} / 50 \mathrm{ml}$ の䀼度範囲で Beer の法 則が非常によく成立する。モル吸光係数は約 2650 (臭素) および 約 4200(ヨウ素)である。臭素イオン $0.393 \mathrm{mg}$ をとったときの 吸光度の標準偏差は 0.0023，変動係数は 0.88\% であり，ヨウ素 イオン $0.627 \mathrm{mg}$ をとったときのそれらは 0.0010 および $0.24 \%$ であって，ともに再現性はよい。なおモル吸光係数と原子量の閶 係で，臭素扎よびョウ素イオンの検量線は図 1 に示すように偶然 一致した。

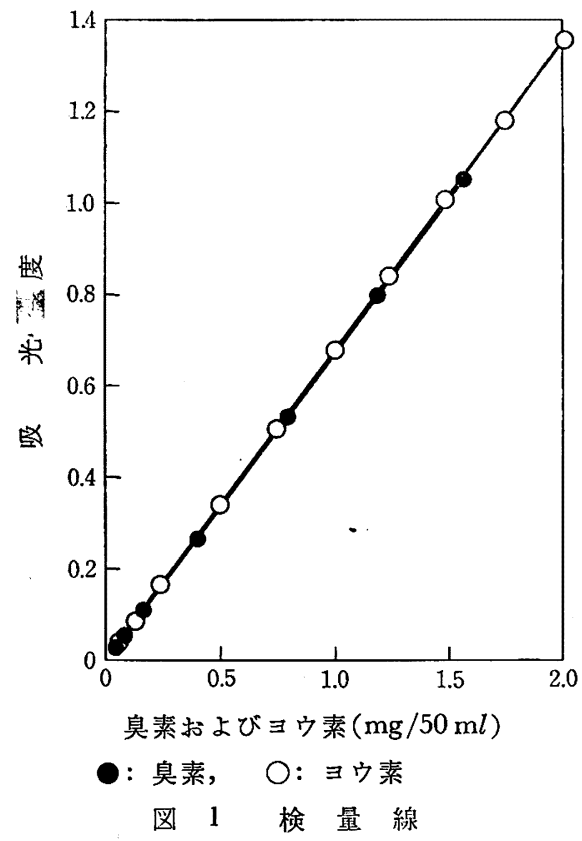

\section{4 定量条件の検討}

\section{$4.1 \mathrm{KBr}, \mathbf{K I}, \mathbf{H g}-\mathbf{E D T A},(\mathbf{K B r}+\mathbf{H g}-\mathbf{E D T A}) お よ ひ ゙(\mathbf{K I}+$} Hg-EDTA) 各溶液の吸収曲線

臭化カリウム，ヨウ化カリウムおよび Hg-EDTA のそれぞれ $1 \times 10^{-3} \mathrm{~mol} / l$ 溶液各 $5 \mathrm{ml}$ を別々の $50 \mathrm{ml}$ ×スフラスコにとり, それらに緩衙液 $20 \mathrm{~m} l$ を加えで $p \mathrm{H}$ を 6.3 に調製後, 水で標線ま でうすめ，同量の緩衝液だけが入っている溶液を対照にして各波 長における吸光度を測定した吸収曲線が図 2 (1)，(2)，(3)であ る。つぎに莧化カリウムおよび Hg-EDTA の $1 \times 10^{-3} \mathrm{~mol} / l$ 溶 液各 $5 \mathrm{ml}$ を同一の $50 \mathrm{ml}$ ×スフラスコにとり, $p \mathrm{H} 6.3$ にして 全容 $50 \mathrm{ml}$ にし, 約 20 分放置後, $p \mathrm{H} 6.3$ の緩衝液を対照にし て求めた吸収曲線が(4)である。またヨウ化カリウムおよび $\mathrm{Hg}$ EDTA の $1 \times 10^{-3} \mathrm{~mol} / l$ 溶液各 $5 \mathrm{ml}$ をとって上と同様に操作し て求めた吸収曲線が(5)である。これから $250 \mathrm{~m} \mu$ 以上の波長で の吸光度をくらべると(4)の吸光度は(1) と(3)の吸光度の和より, (5)では(2)と(3)の吸光度の和よりそれぞれ大きくなっている。 このことから莫素イオンまたはヨウ素イオンは Hg-EDTA と反 応して四光度の大きいなんらかの新化合物を形成していると考え てよい。

\section{2 当量関係}

4.1 の結果から臭素イオンやヨウ絜イオンもチオシアン酸イオ ン2) やシアンイオン3) と同棑な鍇体を形成していると考えられる ので，それらの当量関係を検封した。 $1 \times 10^{-3} \mathrm{~mol} / l$ 臭化カリウ ム溶液または $1 \times 10^{-3} \mathrm{~mol} / l \exists ウ$ 化カリウム溶液各 $5 \mathrm{ml}$ をとっ

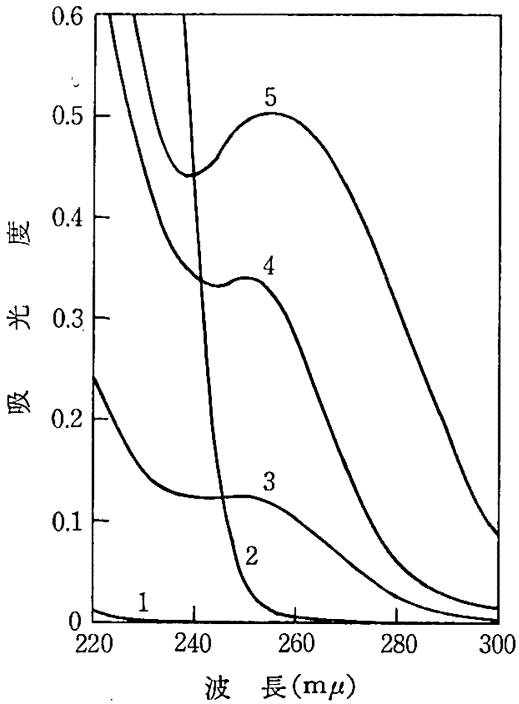

(1): $\mathrm{KBr}, \quad$ (2): KI, (3): Hg-EDTA,

(4):( $\mathrm{KBr}+\mathrm{Hg}-\mathrm{EDTA}),(5):(\mathrm{KI}+\mathrm{Hg}-\mathrm{EDTA})$

図 $2 \mathrm{KBr}, \mathrm{KI}, \mathrm{Hg}$-EDTA, $(\mathrm{KBr}+\mathrm{Hg}$-EDTA)および $(\mathrm{KI}+\mathrm{Hg}-\mathrm{EDTA})$ の吸収曲線

て緩衝液 $20 \mathrm{ml}$ を加えて，それぞれを $p \mathrm{H} 6.3$ に調製する。こ の各溶液に $1 \times 10^{-3} \mathrm{~mol} / l \mathrm{Hg}$-EDTA 溶液を順次増加させて一 定量ずつ加え, 水で全容 $50 \mathrm{~m} l$ にして約 20 分放置後, 各溶液の 吸光度を試薬ブランク液を対照にして波長 $250 \mathrm{~m} \mu$ (臭素)または $260 \mathrm{~m} \mu$ (ヨウ素)で測定し，モル比法で当量関係を求めたのが図 3 である。臭素イオンまたはヨウ素イオンと Hg-EDTA とはモル 比 1:1 で反応している。また，念のために上記 20 分放置後の 各溶液を常法11により PAN 指示薬を用いて硫酸銅標準液で滴定 したが，硫酸銅標準液を消費しないので EDTA は遊離していな いことになって，つぎの反応は起らないことになる。

$$
\begin{aligned}
& \mathrm{HgY}^{2-}+2 \mathrm{Br}^{-} \longrightarrow \mathrm{HgBr}_{2}+\mathrm{Y}^{4-} \\
& \mathrm{HgY}^{2-}+2 \mathrm{I}^{-} \longrightarrow \mathrm{HgI}_{2}+\mathrm{Y}^{4-}
\end{aligned}
$$

したがってチオシアン酸イオンなどと同様に Hg-EDTA・とつ ぎのように反応していると考えてよい。

$$
\begin{aligned}
& \mathrm{HgY}^{2-}+\mathrm{Br}^{-} \longrightarrow[\mathrm{HgY}(\mathrm{Br})]^{3-} \\
& \mathrm{HgY}^{2-}+\mathrm{I}^{-} \longrightarrow[\mathrm{HgY}(\mathrm{I})]^{3-}
\end{aligned}
$$

なお，シアンイオン12) は $[\mathrm{HgY}(\mathrm{GN})]^{3-}$ 溶液とさらに反応し てつぎのように当量の EDTA を遊嗺したが，臭素イオンやヨウ 素イオンはこのような反応を示さない。

$$
[\mathrm{HgY}(\mathrm{CN})]^{3-}+\mathrm{CN}^{-} \longrightarrow \mathrm{Hg}(\mathrm{CN})_{2}+\mathrm{Y}^{4-}
$$

\section{3 吸光度測定用波長}

図３でわかるように臭秦イオンはほとえど定量的に，またヨウ 悲イオンは定量的に Hg-EDTA と反応して鍇体を形成するので, 図 1 (4) は $[\mathrm{HgY}(\mathrm{Br})]^{3-}$ の吸収此線を, (5) は $[\mathrm{HgY}(\mathrm{I})]^{3-}$ の吸 収曲線に相当する。 $[\mathrm{HgY}(\mathrm{Br})]^{3-}$ 錕体は波長 $240 \mathrm{~m} \mu$ 以下にな るにしたがい吸光度を增すが， $240 \mathrm{~m} \mu$ 以下になると定量の際過 剩に用いる $\mathrm{Hg}$-EDTA の吸収も大きくなり試薬ブランク効照液 の 100 あわせが困難になるので，吸光度測定波長は $250 \mathrm{~m} \mu$ を用

11）たとえば，上野景平，“キレート渢完法”，南江堂(1960) p.104.

12) 小松寿美雄, 野村俊明, 日化, 87, 1060(1966). 


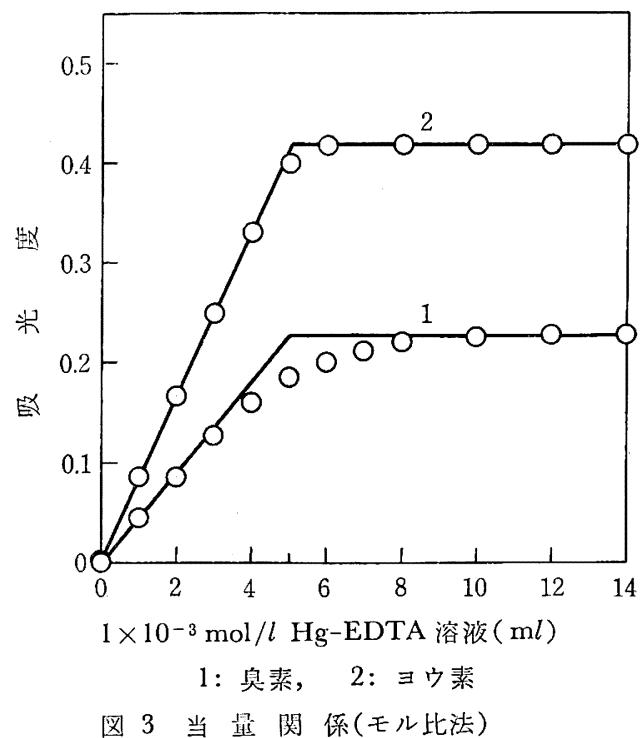

いることにした。また $[\mathrm{HgY}(\mathrm{I})]^{3-}$ 鍇体のときも同様の立場から $260 \mathrm{~m} \mu$ を用いることにした。

\section{4 pH の影響}

鍇体形成反応におよぼす $p \mathrm{H}$ の影響を調べた。 $5 \times 10^{-3} \mathrm{~mol} / l$ $\mathrm{Hg}$-EDTA 溶液 $5 \mathrm{ml}$ をとり, $p \mathrm{H}$ だけを順次変化させた各溶液 に臭秦イオン $0.393 \mathrm{mg}$ を加え, 全容 $50 \mathrm{ml}$ にし, 以下 4.2 と同 様に操作して波長 $250 \mathrm{~m} \mu$ で吸光度を測定したのが図 4 (1)であ る。 $p \mathrm{H} 3.2$ 以下および 8.3 以上では吸光度は急激に減少して錯 体形成反応は不完全である。これから $p \mathrm{H}$ 3.5 7.7 の範囲が適 当であるが $p H 6.3$ で反応を行なうことにした。 ヨウ素イオン の場合は $0.627 \mathrm{mg}$ をとって $1 \times 10^{-3} \mathrm{~mol} / l \mathrm{Hg}$-EDTA 溶液 10 $\mathrm{m} l$ を用いて同様に操作して波長 $260 \mathrm{~m} \mu$ で吸光度を測定したの

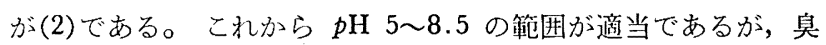
素イオンの場合と同様に $p \mathrm{H} 6.3$ で反応を行なうことにした。

\section{5 反応時間}

臭素イオン $0.393 \mathrm{mg}$ をとり, $p \mathrm{H} 6.3$ に調製後 $5 \times 10^{-3} \mathrm{~mol} /$ $l \mathrm{Hg}-\mathrm{EDTA}$ 溶液 $5 \mathrm{~m} l$ を加光, 水で全容 $50 \mathrm{~m} l$ にし, 試薬ブラ

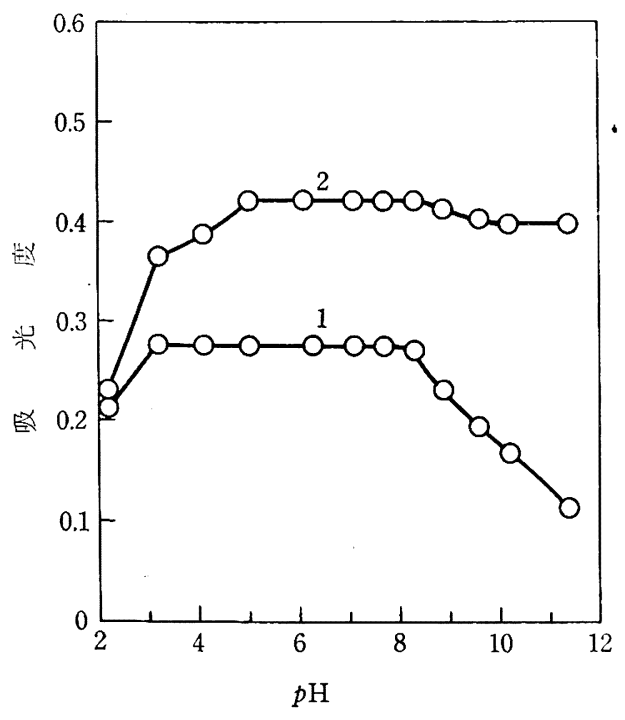

1: 臭箖, 2: 2 ウ絜

図 4 pH 0 影暗
ンク湤を対照にして波長 $250 \mathrm{~m} \mu て ゙$ 四光度を測定して経時変化を 調べたのが図 5 (1)である。また，ヨウ素イオン $0.627 \mathrm{mg}$ をと り, $p \mathrm{H} 7.1$ に調製後 $1 \times 10^{-3} \mathrm{~mol} / l \mathrm{Hg}-\mathrm{EDTA}$ 溶液 $10 \mathrm{ml}$ を 加えたものについて波長 $260 \mathrm{~m} \mu$ で同様に経時変化を調べたのが (2)である。両イオンとも錯体形成反応はすぐに終了して吸光度 は一定になり, 以後 100 分でも吸光度は恋化しないので, 反応 2 , 3 分後に吸光度を測定すればよい。

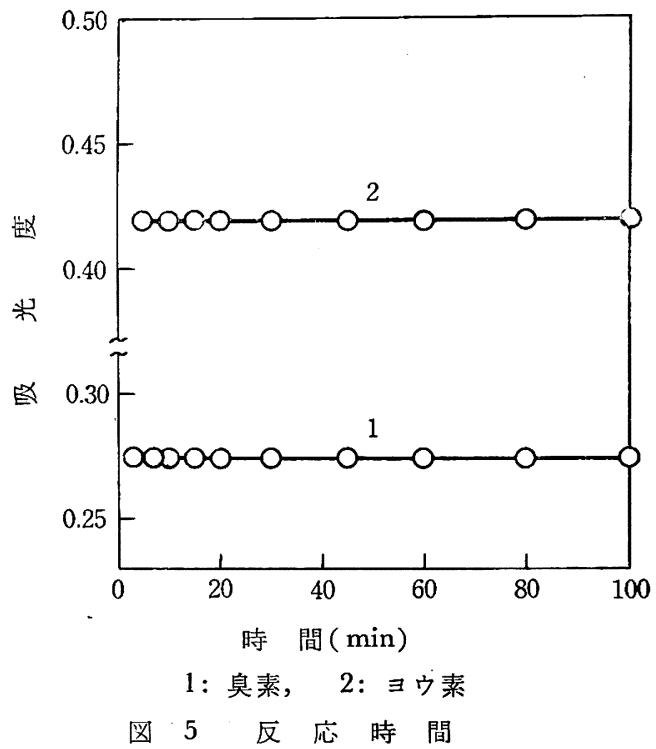

\section{$4.6 \mathrm{Hg}$-EDTA 溶液の採取量}

本定量操作の性質上 Hg-EDTA は臭素イオンなどに対して過 剩に加えなければならない。そこで臭素イオンのときは検量線を 実際求めるには，臭素イオンに対してモル比で 1:1 の当量より もやや過剩の Hg-EDTA 添加では不十分であった。実験の結果 モル比で臭素イオンの約 3 倍以上の添加が必要であることがわか ったが，さらに過剩の添加でも妨害にならない。臭素イオンの定 量上限を $1.6 \mathrm{mg} / 50 \mathrm{ml}$ にすると, モル比でこの 3 倍量を添加す るには $5 \times 10^{-3} \mathrm{~mol} / l \mathrm{Hg}-\mathrm{EDTA}$ 溶液 $10 \mathrm{ml}$ を必要とすること になる。これは図 3 に示すように錯体はやや不安定であるので, 鍇化剤の Hg-EDTA を相当過剩に添加して安定化する必要があ るからである。4.4, 4.5 などの実験ではすべて臭素イオンに対す る Hg-EDTA 添加量はモル比で 3 倍以上になっている。

つぎに、ヨウ素イオンの実験ではすべて $1 \times 10^{-3} \mathrm{~mol} / l \mathbf{~ H g}$ EDTA 溶液 $10 \mathrm{ml}$ を用いたが，これは当量関係からすればョウ 素約 $1.27 \mathrm{mg}$ に相当する。ヨウ素 $1.1 \mathrm{mg}$ のときの吸光度は 0.75 になるのでまだ定量上限を拡げてもよいわけである。したがって 椧量線を求めるときには $2 \times 10^{-3} \mathrm{~mol} / l \mathrm{Hg}$-EDTA 溶液 $10 \mathrm{ml}$ を用いた。

\section{7 共存イオンの影響}

系素イオン $0.393 \mathrm{mg}$ またはヨウ素イオン $0.627 \mathrm{mg}$ をとった ときの共存イオンの影揞を示したのが表 1 , 裴 2 である。>符号 のものはこれ以上の量については众討しなかったものであり，備 考欄の $(+) ，($ ）はそれぞれ吸光度，すなわち定量值に正誤差を 与えるもの，負誤差を与えるものとした。なお吸光度に対して $\pm 1 \%$ 以上の誤差它与えるときを妙害するとした。

$\mathrm{S}^{2+}$ が奶管与るのは Hg-EDTA 中の水銀乞硫化水銀定つくり， 
表 1 共存イオンの妨害限度量(臭素イオンのとき)

\begin{tabular}{|c|c|c|c|}
\hline イオン & 添加された形 & 限 度 量 & 備 考 \\
\hline $\mathrm{CN}^{-}$ & $\mathrm{KCN}$ & コン跡 & - \\
\hline $\mathrm{SCN}^{-}$ & $\mathrm{KSCN}$ & " & + \\
\hline $\mathrm{S}^{2-}$ & $\mathrm{Na}_{2} \mathrm{~S} \cdot 9 \mathrm{H}_{2} \mathrm{O}$ & " & + \\
\hline $\mathrm{I}^{-}$ & $\mathrm{KI}$ & $5 \mu \mathrm{g}$ & + \\
\hline $\mathrm{Cl}^{-}$ & $\mathrm{NaCl}$ & $15 \prime \prime$ & + \\
\hline $\mathrm{S}_{2} \mathrm{O}_{3}{ }^{2-}$ & $\mathrm{Na}_{2} \mathrm{~S}_{2} \mathrm{O}_{3} \cdot 5 \mathrm{H}_{2} \mathrm{O}$ & $10 "$ & + \\
\hline $\mathrm{SO}_{4}{ }^{2-}$ & $\mathrm{K}_{2} \mathrm{SO}_{4}$ & $>50 \mathrm{mg}$ & \pm \\
\hline $\mathrm{ClO}_{4}^{-}$ & $\mathrm{NaClO}_{4}$ & $>50 "$ & \pm \\
\hline $\mathrm{NO}_{3}^{-}$ & $\mathrm{KNO}_{3}$ & 11 & + \\
\hline $\mathrm{Co}^{2+}$ & $\mathrm{CoSO}_{4} \cdot 7 \mathrm{H}_{2} \mathrm{O}$ & コン跡 & - \\
\hline $\mathrm{NH}_{4}{ }^{+}$ & $\left(\mathrm{NH}_{4}\right)_{2} \mathrm{SO}_{4}$ & $20 \mu \mathrm{g}$ & - \\
\hline $\mathrm{Th}^{4+}$ & $\mathrm{Th}\left(\mathrm{NO}_{3}\right)_{4}$ & $100 "$ & + \\
\hline $\mathrm{Fe}^{3+}$ & $\mathrm{Fe}\left(\mathrm{NO}_{3}\right)_{3} \cdot 9 \mathrm{H}_{2} \mathrm{O}$ & $10 "$ & + \\
\hline $\operatorname{In}^{3+}$ & $\mathrm{In}_{2}\left(\mathrm{SO}_{4}\right)_{3}$ & $25 "$ & + \\
\hline $\mathrm{VO}_{3}^{-}$ & $\mathrm{NaVO}_{3}$ & $10 "$ & + \\
\hline $\mathrm{Mo}^{6+}$ & $\mathrm{Na}_{2} \mathrm{MoO}_{4} \cdot 2 \mathrm{H}_{2} \mathrm{O}$ & $15 \prime$ & + \\
\hline $\mathrm{Cu}^{2+}$ & $\mathrm{CuSO}_{4} \cdot 5 \mathrm{H}_{2} \mathrm{O}$ & $30 "$ & + \\
\hline $\mathrm{Ni}^{2+}$ & $\mathrm{NiSO}_{4} \cdot 7 \mathrm{H}_{2} \mathrm{O}$ & $20 "$ & - \\
\hline $\mathrm{Hg}^{2+}$ & $\mathrm{Hg}\left(\mathrm{NO}_{3}\right)_{2}$ & $200 "$ & - \\
\hline $\mathrm{Ag}^{+}$ & $\mathrm{AgNO}_{3}$ & $10 "$ & + \\
\hline
\end{tabular}

$\mathrm{Ag}^{+}$は臭化銀，ヨウ化銀をつくってこれらが紫外部に相当吸収が あるためである。 $\mathrm{NH}_{4}{ }^{+13)}, \mathrm{SCN}^{-2)}, \mathrm{CN}^{-3)}$ などは臭素イオン と同形式の錯体を形成するために妨害になる。しかし， $\mathrm{NH}_{4}+$ や $\mathrm{CN}^{-3)}$ の錯体の吸収は波長 $250 \mathrm{~m} \mu$ ないし $260 \mathrm{~m} \mu$ 付近では 13）上野景平, “キレート滴定法”, 南江堂 (1960)p. 331.
表 2 共存イオンの妨害限度量( ヨウ垁イオンのとき)

\begin{tabular}{|c|c|c|c|}
\hline イオン & 添加された形 & 限 度 量 & 潇 考 \\
\hline $\mathrm{S}^{2-}$ & $\mathrm{Na}_{2} \mathrm{~S} \cdot 9 \mathrm{H}_{2} \mathrm{O}$ & コン跡 & + \\
\hline $\mathrm{CN}^{-}$ & $\mathrm{KGN}$ & $10 \mu \mathrm{g}$ & - \\
\hline $\mathrm{SCN}^{-}$ & KSCN & $10 "$ & + \\
\hline $\mathrm{Br}^{-}$ & $\mathrm{KBr}$ & $10 "$ & + \\
\hline $\mathrm{Cl}^{-}$ & $\mathrm{NaCl}$ & $100 "$ & + \\
\hline $\mathrm{S}_{2} \mathrm{O}_{3}{ }^{2-}$ & $\mathrm{Na}_{2} \mathrm{~S}_{2} \mathrm{O}_{3} \cdot 5 \mathrm{H}_{2} \mathrm{O}$ & $30 "$ & + \\
\hline $\mathrm{SO}_{4}{ }^{2-}$ & $\mathrm{K}_{2} \mathrm{SO}_{4}$ & $>100 \mathrm{mg}$ & \pm \\
\hline $\mathrm{NO}_{3}^{-}$ & $\mathrm{KNO}_{3}$ & $10 "$ & + \\
\hline $\mathrm{ClO}_{4}^{-}$ & $\mathrm{NaClO}_{4}$ & $>100 "$ & \pm \\
\hline $\mathrm{NH}_{4}^{+}$ & $\left(\mathrm{NH}_{4}\right)_{2} \mathrm{SO}_{4}$ & $5 \mu \mathrm{g}$ & - \\
\hline $\mathrm{Th}^{4+}$ & $\operatorname{Th}\left(\mathrm{NO}_{3}\right)_{4}$ & $500 "$ & + \\
\hline $\mathrm{Fe}^{3+}$ & $\mathrm{Fe}\left(\mathrm{NO}_{3}\right)_{3} \cdot 9 \mathrm{H}_{2} \mathrm{O}$ & $15 "$ & + \\
\hline $\operatorname{In}^{3+}$ & $\mathrm{In}_{2}\left(\mathrm{SO}_{4}\right)_{3}$ & $200 "$ & + \\
\hline $\mathrm{VO}_{3}^{-}$ & $\mathrm{NaVO}_{3}$ & $10 "$ & + \\
\hline $\mathrm{Mo}^{6+}$ & $\mathrm{Na}_{2} \mathrm{MoO}_{4} \cdot 2 \mathrm{H}_{2} \mathrm{O}$ & $100 "$ & + \\
\hline $\mathrm{Cu}^{2+}$ & $\mathrm{CuSO}_{4} \cdot 5 \mathrm{H}_{2} \mathrm{O}$ & $150 "$ & + \\
\hline $\mathrm{Co}^{2+}$ & $\mathrm{CoSO}_{4} \cdot 7 \mathrm{H}_{2} \mathrm{O}$ & $5 \prime \prime$ & - \\
\hline $\mathrm{Ni}^{2+}$ & $\mathrm{NiSO}_{4} \cdot 7 \mathrm{H}_{2} \mathrm{O}$ & $50 "$ & - \\
\hline $\mathrm{Hg}^{2+}$ & $\mathrm{Hg}\left(\mathrm{NO}_{3}\right)_{2}$ & $20 "$ & - \\
\hline $\mathrm{Ag}^{+}$ & $\mathrm{AgNO}_{3}$ & $5 "$ & + \\
\hline
\end{tabular}

$\mathrm{Hg}$-EDTA の吸収より小さいために負誤差になる。金属陽イオ ンについては EDTA に対するキレート生成定数が水銀より大き いものについて主として检討した。また実際分析としては $\mathrm{Cl}^{-}$, $\mathrm{Br}^{-}, \mathrm{I}^{-}$共存時の $\mathrm{Br}^{-}$ないし $\mathrm{I}^{-}$の定量法について検討すべき であるがこれについては後日研究したい。

\title{
$\boldsymbol{N}$-ブロムコハク酸イミドの滴下水銀電極におけるポーラログラフ的挙動
}

\author{
(昭和 41 年 8 月 4 日受理 )
}

永井外代士・松田十四夫*1

\begin{abstract}
N-ブロムコハク酸イミド(NBS)は容量分析における選択的な酸化削として知られているが，そのポーラログラフ的挙動について はNBS が滴下水銀電極で容易に還元されるという Zuman の記述があるのみである。NBS $0.1 \mathrm{~mol} / \mathrm{l}$ 硝酸カリウム，Britton一 Robinson 䌅衝溶液（pH 5.0）および 0.01\% ポリアクリルアミドを含む支持電解質溶液中で， 2 電子の関与する限界還元電流を示 すが，電極反応生成物の臭素イオンによる水銀溶出波と混液電位を示し，そのため 2 段波を与える。NBS の第 1 波および全波の 限界電流は拡散律速であり，0V vs. SCE での NBS の拡散電流值は $4 \times 10^{-3} \sim 2 \times 10^{-5} \mathrm{~N}$ の浱度籁囲で浱度に比例する。pHに よる NBS の拡散電流の変化および電極水銀，ポリフクリルアミドとの反応によるNBS の分解の影㗽について検討した。
\end{abstract}

\section{1 緒言}

$N$-ブロムコハク酸イミド(NBS)は +1 価の臭素を含み，選択 的な酸化剂および臭素添加戍として分析化学，有機化学において 用いられている1)。NBS と種々の化合物との酸化還元反応が検討 されており2)，アスコルビン酸3， ヒドラジンとその誘導(体4)お

*1 Toyoshi NAgAI, Toshio MAtsuda 立命館大学理工学 部化学教室, 京都市北区等持院北町

1) A. Berka, J. Vulterin, J. Zýka, "Newer Redox Titrants", Pergamon Press(1965) p. 52; R. Filler, Chem. Revs., 63, 21 (1963).

2) A. Berka, J. Zýka, Collection Czechoslov. Chem. Commun., 23, 402(1958).

3) M. Z. Barakat, M. F. A. El-Wahab, M. M. El-Sadr, Anal. Chem., 27, 536(1955).

4) M. Z. Barakat, M. Shaker, Analyst, 88, 59(1963).
よびアンチモン $(\mathbb{I I})^{5)}$ などの定量が報告されている。これらの定 量にはメチルレッドを指示莯としている。また NBS とゼラチン などとの反応についての報告もみられる6)。

一方 NBS の電気分析化学的な挙動についての報告は, “NBS が滴下水銀電㥛において容易に還元される”というZumanの未 発表の紹介》があるのみである。著者らは NBS を電示容量分析 に邂用する目的で，まず滴下水銀電極でのポーラログラフ的挙動 について検討した。

その結果, NBS は $0.1 \mathrm{~mol} / l$ 硝酸カリウム, Britton-Robinson

5) M. Z. Barakat, S. K. Shehab, Analyst, 90, 50(1965).

6) 奥山典生, 佐藤成美，他，日化，86，443(1965).

7) M. Brezina, P. Zuman, "Polarography in Medicine, Biochemistry and Pharmacy", Interscience Pub. Inc., New York(1958)p. 223. 